\title{
Application of Sephadex LH-20 for Microdetermination of Dopamine by Solid Phase Spectrophotometry
}

\author{
Mehdi Taghdiri and Arash Mohamadipour-taziyan \\ Department of Chemistry, Payame Noor University, P.O. Box 19395-3697, Tehran, Iran \\ Correspondence should be addressed to Mehdi Taghdiri, mehditaghdiri@yahoo.com
}

Received 23 October 2012; Accepted 7 November 2012

Academic Editors: J. Lee, L. Pezza, and C. Zacharis

Copyright ( $\odot 2012$ M. Taghdiri and A. Mohamadipour-taziyan. This is an open access article distributed under the Creative Commons Attribution License, which permits unrestricted use, distribution, and reproduction in any medium, provided the original work is properly cited.

\begin{abstract}
A sensitive spectrophotometric method for the determination of dopamine was carried out without any separation steps. Bromocresol green is adsorbed on Sephadex LH-20 gel but the sorption decreases in the presence of dopamine due to ionpair formation between bromocresol green and dopamine in solution. This attenuation was used to the microdetermination of dopamine by measurement of absorbance of the solid phase (Sephadex LH-20 gel) in a $1.0 \mathrm{~mm}$ cell at $625 \mathrm{~nm}$. Dopamine could be determined in the concentration range of $0.4-1.6 \mu \mathrm{g} \mathrm{mL} \mathrm{L}^{-1}(10-\mathrm{mL}$ Sample volume) with a relative standard deviation (RSD) of $0.03 \%(n=4)$. The detection limit was obtained, $0.26 \mu \mathrm{g} \mathrm{mL}^{-1}(1.7 \mu \mathrm{M})$. The method was used for determination of dopamine in pharmaceutical injection sample and satisfactory result was obtained.
\end{abstract}

\section{Introduction}

Dopamine (DP) has been used for treating all kinds of shock syndromes. It is very important to find a simple and sensitive method to determine the content of DP in clinical medicine. Pharmaceutical quality standard of many countries describes a nonaqueous titration method for determination of DP in injection, for example, the 1990 edition of Chinese pharmacopoeia and USP XXI. HPLC method was described for the determination of DP in USP 24 and BP 2000 with expensive apparatus [1]. Chemiluminescence has also been applied to determine DP; however, chemiluminescence reactants have hardly found extensive applications due to the instability of the oxidation reagents $[2,3]$. Electrochemical detection methods have also been introduced since these are the best ways to directly determine DP without any separation steps of samples. The existence of ascorbic acid (AA) is the main obstacle in electrochemical detection system since AA is oxidized at similar potentials to DP at conventional electrodes. Therefore, modified electrodes have been used to simultaneously detect both DP and AA at different potentials [4-12]. The spectrophotometry has also been used for determination of DP with the use of organic compounds that react with DP [13-20].
However, in this work, the determination of DP is carried out with inhibition of the sorption of bromocresol green (BCG) on a solid phase from an aqueous solution, and the subsequent measurement of absorption, directly in the solid phase. Solid phase spectrophotometry (SPS) in visible region has been less used for determination of organic compounds [21]. We present an innovative work to use SPS in visible region for determination of DP. A higher molar absorptivity was obtained by this proposed method than other spectrophotometric methods.

Dopamine forms an ion-pair with BCG in solution and therefore, the sorption of BCG on the solid phase decreases. We used the Sephadex LH-20 as solid phase. Sephadex LH20 medium is based on hydroxypropylated dextran that has been cross-linked to yield a polysaccharide network (Figure 1).

\section{Materials and Methods}

2.1. Materials and Solutions. Citric acid, sodium hydroxide, potassium hydroxide, sodium acetate, sodium ascorbate, acetic acid, and bromocresol green (all from Merck) were of the highest purity available and were used as received. 


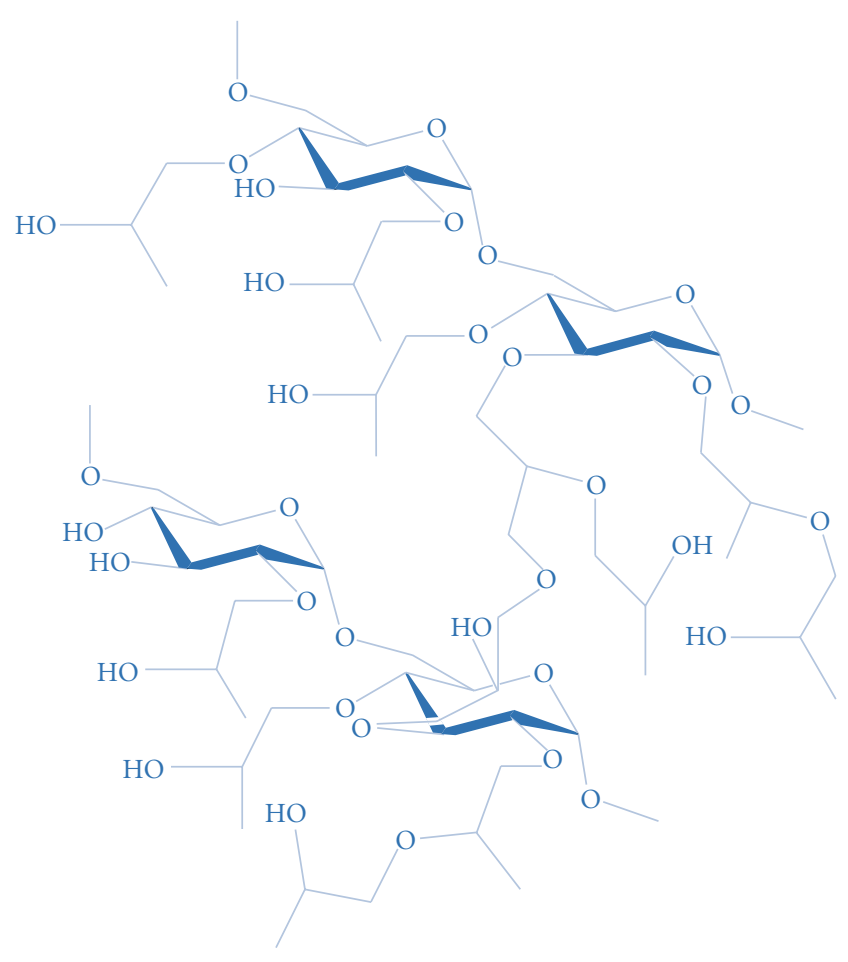

FIgURE 1: Partial structure of Sephadex LH-20.

3-Hydroxytyramine hydrochloride (Dopamine, 99\%) was purchased from Acros Organics.

The Sephadex LH-20 gel (mesh $25-100 \mathrm{~mm}$ ) (Aldrich) in its original dry state without pretreatment was used as solid support. Dowex 1-X8 (200-400 mesh) anion exchange resin (Bio-Rad) was used in the chloride form for removal of ascorbate interference.

The stock solution was prepared by dissolving an appropriate amount of DP in water to obtain a concentration of $3.0 \times 10^{-4} \mathrm{M}$. Citrate buffer, $\mathrm{pH} 4.0$ was prepared by titrating aqueous $0.1 \mathrm{M}$ disodium citrate $(19.2 \mathrm{~g}$ citric acid $+200 \mathrm{~mL}$ of $1 \mathrm{M} \mathrm{NaOH} / 1000 \mathrm{~mL} \mathrm{H}_{2} \mathrm{O}$ ) with $0.1 \mathrm{M} \mathrm{HCl}$. Bromocresol green was dissolved in $4.0 \times 10^{-4} \mathrm{M} \mathrm{NaOH}$ and was diluted to $100.0 \mathrm{~mL}$ with the $\mathrm{pH} 4.0$ citrate buffer to produce a 1.0 $\times 10^{-4} \mathrm{M}$ solution. Buffer solutions and bromocresol green stock solutions were adjusted to an ionic strength of 0.2 with $\mathrm{KCl}$. The pharmaceutical injection sample (Dopadic) was from Caspian Tamin Pharmaceutical Co., Iran.

2.2. Apparatus. Weighing of materials was performed by using an analytical balance model Sartorius MCBA 100 with precision of $\pm 0.0001 \mathrm{~g}$. $\mathrm{pH}$ measurements were carried out with a Metrohm $691 \mathrm{pH}$-meter. A GBC spectrophotometer model Cintra 6 was used for spectrophotometric measurements.

2.3. Procedures. A $10 \mathrm{~mL}$ sample containing $0.4-1.6 \mu \mathrm{g} \mathrm{m}^{-1}$ of DP was transferred to a $100 \mathrm{~mL}$ Beaker and then $4 \mathrm{~mL}$ of $1.0 \times 10^{-4} \mathrm{M}$ BCG was added. The mixture was stirred mechanically for $4 \mathrm{~min}$. Then $70 \mathrm{mg}$ of Sephadex LH-20 (25-100 mesh) gel was added and the mixture was stirred
TABLE 1: Analytical parameters.

\begin{tabular}{|c|c|}
\hline Intercept & 0.0897 \\
\hline Slope $\left(\mathrm{mL} \mu \mathrm{g}^{-1}\right)$ & 0.1164 \\
\hline Linear dynamic range $\left(\mu \mathrm{g} \mathrm{mL}^{-1}\right)$ & $0.4-1.6$ \\
\hline Correlation coefficient & 0.9904 \\
\hline RSD (\%) & 0.03 \\
\hline Detection limit $\left(\mu \mathrm{g} \mathrm{mL}^{-1}\right)$ & 0.26 \\
\hline$\Delta \mathrm{A}$ for sample & $0.1096 \pm 0.0012^{\mathrm{a}}$ \\
\hline
\end{tabular}

${ }^{a}$ Average of three determinations.

mechanically for $5 \mathrm{~min}$ and the coloured gel was collected by centrifuge and, using a little pipette, packed into a $1 \mathrm{~mm}$ cell together with a small volume of the filtrate. The cell was centrifuged at $2500 \mathrm{rpm}$ for $1 \mathrm{~min}$. A blank solution containing all the reagents except DP was prepared and treated in the same way as the sample. The absorbance (really attenuation) of Sephadex LH-20 gel was measured at $625 \mathrm{~nm}$ (corresponding to the absorption maximum of the BCG) and $800 \mathrm{~nm}$ (the latter is in the 700-850 $\mathrm{nm}$ range, where only the gel "absorbs" light) and compared with a $1 \mathrm{~mm}$ cell packed with gel equilibrated with blank solution. The absorbance difference between sample and blank provides an estimation of the net absorbance.

DP injection solution ( $200 \mathrm{mg}$ per $5 \mathrm{~mL}$ ) was appropriately diluted with water to get the required concentration of the drug, and then the general procedure was followed. The amount of DP was calculated from a calibration graph.

\section{Results and Discussion}

3.1. Absorption Spectra. The BCG color reagent $\left(\mathrm{pK}_{a}=4.66\right)$ occurs in two acid-base forms in weakly acidic aqueous solutions with the absorption maximum at $430 \mathrm{~nm}\left(\mathrm{BCGH}^{-}\right.$ form) and $615 \mathrm{~nm}\left(\mathrm{BCG}^{2-}\right)$ [22]. When this triarylmethane dye forms ion-pair with $\mathrm{DPH}^{+}$in citrate buffer solution at $\mathrm{pH} 4.0$, it is not adsorbed on Sephadex LH-20 gel. Therefore, the absorbance difference between solid phase prepared in the absence and in the presence of DP is proportional to DP concentration in solution (Figure 2).

\subsection{Optimization of Conditions}

3.2.1. $\mathrm{pH}$ Dependence. Optimum $\mathrm{pH}$ for the formation of ion-pair and fixation of BCG on Sephadex LH-20 falls below 4.0 (Figure 3). At $\mathrm{pH}$ values of above 4.0 the net absorbance of the solid phase increased due to a decrease in the formation of ion-pair. In $\mathrm{pH}$ 3.0, the monoanionic form of BCG is predominant and then solid phase is yellow with the absorption maximum at $435 \mathrm{~nm}$ but the solid phase is green in $\mathrm{pH} 4.0$ with the absorption maximum at $625 \mathrm{~nm}$. We chose $\mathrm{pH} 4.0$ as the optimum $\mathrm{pH}$ value for the procedure because the absorbance of solid phase was further from UV region. The best of the buffer systems examined was citric acid-citrate $(\mathrm{pH}=4)$.

3.2.2. Other Experimental Conditions. The optimum stirring time before and after adding of Sephadex LH-20 were 4 min 
TABLE 2: Comparison of sensitivity of some spectrophotometric methods for the determination of dopamine.

\begin{tabular}{|c|c|c|}
\hline Method & Molar absorptivity $\left(\mathrm{L} \cdot \mathrm{mol}^{-1} \cdot \mathrm{cm}^{-1}\right)$ & Reference \\
\hline Reaction with 1,2-naphthoquinone-4-sulfonate & $2.78 \times 10^{3}$ & {$[14]$} \\
\hline Diazotised with sulphamic acid & $4.2 \times 10^{3}$ & {$[16]$} \\
\hline Isoniazid in the presence of $N$-bromosuccinimide & $6.47 \times 10^{3}$ & {$[15]$} \\
\hline Thiosemicarbazide & $2.4 \times 10^{4}$ & {$[20]$} \\
\hline Potassium ferricyanide-Fe(III) & $3.2 \times 10^{4}$ & {$[19]$} \\
\hline Diazotised sulphanilamide in the presence of molybdate & $5.39 \times 10^{4}$ & {$[17]$} \\
\hline Proposed method (solid phase spectrophotometry) & $1.78 \times 10^{5}$ & This work \\
\hline
\end{tabular}

TABLE 3: Effect of ascorbate on the determination of $1.2 \mu \mathrm{g} \mathrm{mL}^{-1}$ of dopamine.

\begin{tabular}{lc}
\hline Ascorbate content $\left(\mu \mathrm{g} \mathrm{mL}^{-1}\right)$ & Absorbance of solid phase \\
\hline 0 & 1.664 \\
0.4 & 1.644 \\
0.4 & $1.664^{\mathrm{b}}$ \\
0.6 & $1.664^{\mathrm{b}}$ \\
\hline
\end{tabular}

${ }^{\mathrm{a}}$ Air as reference, ${ }^{\mathrm{b}}$ After removal of ascorbate by Dowex1-X8.

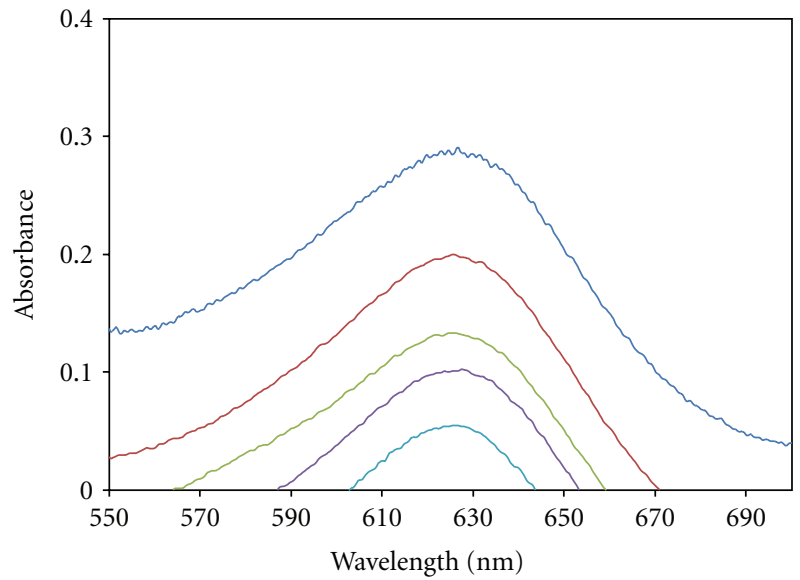

FIGURE 2: The decreases of absorbance of BCG in the Sephadex LH20 phase in the presence of the various amounts of DP (1-mm cell, similarly packed with Sephadex LH-20 equilibrated with water as reference). $[\mathrm{BCG}]=10^{-4} \mathrm{M}, 70 \mathrm{mg}$ Sephadex LH-20; from up to down $[D P]=0.0,0.4,0.8,1.2$ and $1.6 \mu \mathrm{g} \mathrm{mL}^{-1}$.

and $5 \mathrm{~min}$, respectively, (Figure 4). The fixed BCG is stable for at least $80 \mathrm{~min}$ after equilibration. Repeatability of the method is improved if the cells packed with the solid phase are centrifuged before spectrophotometric measurements are taken. The centrifugation time used here was $1 \mathrm{~min}$ at $2500 \mathrm{rpm}$. Sephadex LH-20 of between 25 and $100 \mathrm{mg}$ allow adequate working conditions. A decrease in the amount can result in operational difficulties. For all measurements $70 \mathrm{mg}$ of Sephadex LH-20 was used as a compromise between maximum sensitivity and ease of operation.

3.3. Analytical Data. The calibration graph is reasonably linear for the concentration ranges $0.4-1.6 \mu \mathrm{g} \mathrm{mL}^{-1}$ of DP

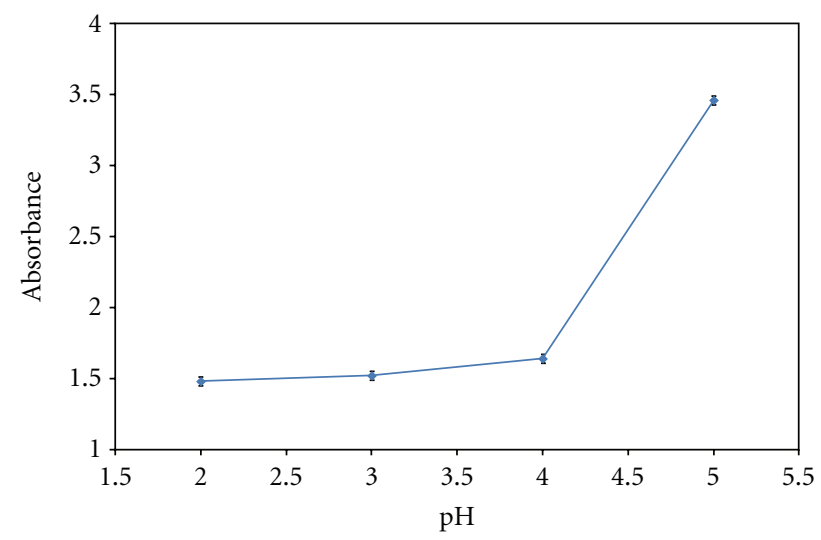

FIGURE 3: Influence of $\mathrm{pH}$ on the absorbance of BCG in solid phase. Conditions: $1.2 \mu \mathrm{g} \mathrm{mL}^{-1}$ of DP; [BCG] $=10^{-4} \mathrm{M}$; $70 \mathrm{mg}$ Sephadex $\mathrm{LH}-20$; sample volume $10 \mathrm{~mL}$ (air as reference).

for the $10 \mathrm{~mL}$ sample system. The analytical parameters are shown in Table 1.

Repeatability was measured for a series of four independent determinations containing $1.2 \mu \mathrm{g} \mathrm{mL}^{-1}$ of DP and was $0.03 \%$.

The sensitivity, expressed as molar absorptivity, of the proposed method is compared in Table 2 with those of published spectrophotometric methods. The higher sensitivity of the proposed method is apparent.

3.4. Interference. An antioxidant, sodium metabisulphate, and sodium chloride that are commonly present in the DP injection, and also commonly used excipients such as starch, talc, glucose, lactose, dextrose, and magnesium stearate, did not interfere.

The most serious interference in the determination of DP in biological samples is ascorbate anion [4-10, 23, 24]. However, this interference can be removed by treating the sample using Dowex 1-X8 anion exchange resin before determining of DP by the SPS method. DP is not adsorbed on Dowex 1-X8 because it is as cationic form (Table 3).

3.5. Determination of DP in Pharmaceutical Sample. The method has been applied to the determination of DP in pharmaceutical sample by calibration curve method ( $\Delta \mathrm{A}$ versus concentration of DP). The result obtained, summarized in Table 4, shows a good agreement with the composition value 


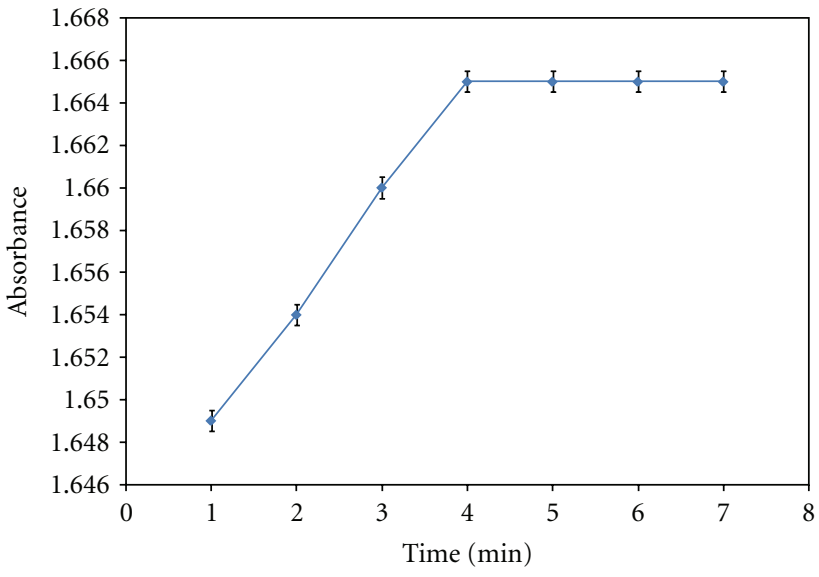

(a)

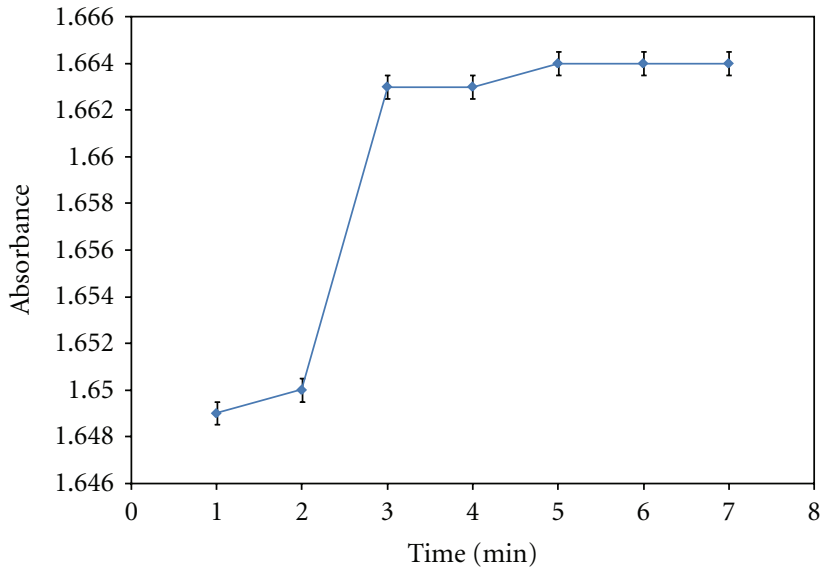

(b)

FIGURE 4: Influence of stirring time on the absorbance of BCG in solid phase. Conditions: $1.2 \mu \mathrm{g} \mathrm{mL} \mathrm{mL}^{-1} \mathrm{of}$; $[\mathrm{BCG}]=10^{-4} \mathrm{M}$; $\mathrm{pH}=4.0$; $70 \mathrm{mg}$ Sephadex LH-20; sample volume $10 \mathrm{~mL}$ (air as reference). (a) before adding of Sephadex LH-20 and (b) after adding of Sephadex LH-20.

TABLE 4: Determination of dopamine in pharmaceutical sample.

\begin{tabular}{lcc}
\hline Drug & $\begin{array}{c}\text { Nominal content } \\
\text { of DP after } \\
\text { dilution }\left(\mu \mathrm{gLL}^{-1}\right)\end{array}$ & $\begin{array}{c}\text { Obtained content } \\
\text { of DP by SPS } \\
\left.(\mu \mathrm{g} \mathrm{mL})^{-1}\right)\end{array}$ \\
\hline $\begin{array}{l}\text { Injection (Marketed by } \\
\text { Caspian Tamin } \\
\text { Pharmaceutical Co.) }\end{array}$ & 1.2 & $1.11 \pm 0.01^{\mathrm{a}}$ \\
\hline
\end{tabular}

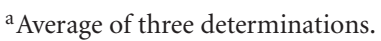

indicated by the supplier. It should be noted that our purpose of this determination is not to assay this pharmaceutical sample but is to indicate the ability of the SPS method in microdetermination of DP. The detection limit of the SPS method is $0.26 \mu \mathrm{g} \mathrm{mL}^{-1}(1.7 \mu \mathrm{M})$.

\section{Conclusions}

Dopamine at the microgram level can be determined efficiently with BCG using the Solid-Phase Spectrophotometry technique without expensive apparatus. The proposed method has been applied to the determination of DP in pharmaceutical sample with good result. The method is simple and more sensitive as compared to others commonly used at the microgram level. The method does not use organic solvents, extra organic compounds as reactants and pretreatment of the sample. Therefore, the method is environmentally friendly and can be considered as a green analytical method. It has been demonstrated that the interference of ascorbate, if it exists in the sample, can be removed by anion exchanger resin and hence, the method can be appropriate for the determination of DP in biological samples.

\section{Conflict of Interests}

The authors do not have any conflict of interests with respect to the conducted study.

\section{References}

[1] N. Yang, J. Li, and L. Zhang, "HPLC determination of dopamine hydrochloride in dopamine hydrochloride and sodium chloride injection," Chinese Journal of Pharmaceutical Analysis, vol. 23, pp. 232-232, 2003.

[2] S. M. Wabaidur, Z. A. Alothman, S. M. Alam, and S. H. Lee, "Flow injection-chemiluminescence determination of dopamine using potassium permanganate and formaldehyde system," Spectrochimica Acta, vol. 96, pp. 221-225, 2012.

[3] M. Grünhut, V. L. Martins, M. E. Centurión, M. C. U. Araújo, and B. S. F. Band, "Flow-batch analyzer for the chemiluminescence determination of catecholamines in pharmaceutical preparations," Analytical Letters, vol. 44, no. 1-3, pp. 67-81, 2011.

[4] H. R. Zare, N. Rajabzadeh, N. Nasirizadeh, and M. Mazloum Ardakani, "Voltammetric studies of an oracet blue modified glassy carbon electrode and its application for the simultaneous determination of dopamine, ascorbic acid and uric acid," Journal of Electroanalytical Chemistry, vol. 589, no. 1, pp. 6069, 2006.

[5] H. R. Zare, N. Nasirizadeh, and M. Mazloum Ardakani, "Electrochemical properties of a tetrabromo-p-benzoquinone modified carbon paste electrode. Application to the simultaneous determination of ascorbic acid, dopamine and uric acid," Journal of Electroanalytical Chemistry, vol. 577, no. 1, pp. 25-33, 2005.

[6] H. Yao, Y. Sun, X. Lin, Y. Tang, and L. Huang, "Electrochemical characterization of poly(eriochrome black T) modified glassy carbon electrode and its application to simultaneous determination of dopamine, ascorbic acid and uric acid," Electrochimica Acta, vol. 52, no. 20, pp. 6165-6171, 2007.

[7] Z. Wang, J. Liu, Q. Liang, Y. Wang, and G. Luo, "Carbon nanotube-modified electrodes for the simultaneous determination of dopamine and ascorbic acid," Analyst, vol. 127, no. 5, pp. 653-658, 2002.

[8] Z. H. Wang, Q. L. Liang, Y. M. Wang, and G. A. Luo, "Carbon nanotube-intercalated graphite electrodes for simultaneous determination of dopamine and serotonin in the presence of ascorbic acid," Journal of Electroanalytical Chemistry, vol. 540, pp. 129-134, 2003. 
[9] C. Wang, R. Yuan, Y. Chai, S. Chen, F. Hu, and M. Zhang, "Simultaneous determination of ascorbic acid, dopamine, uric acid and tryptophan on gold nanoparticles/overoxidizedpolyimidazole composite modified glassy carbon electrode," Analytica Chimica Acta, vol. 741, pp. 15-20, 2012.

[10] S. Thiagarajan and S. M. Chen, "Preparation and characterization of PtAu hybrid film modified electrodes and their use in simultaneous determination of dopamine, ascorbic acid and uric acid," Talanta, vol. 74, no. 2, pp. 212-222, 2007.

[11] G. P. Keeley, N. McEvoy, H. Nolan et al., "Simultaneous electrochemical determination of dopamine and paracetamol based on thin pyrolytic carbon films," Analytical Methods, vol. 4, pp. 2048-2053, 2012.

[12] Z. H. Sheng, X. Q. Zheng, J. Y. Xu, W. J. Bao, F. B. Wang, and X. H. Xia, "Electrochemical sensor based on nitrogen doped graphene: simultaneous determination of ascorbic acid, dopamine and uric acid," Biosensors and Bioelectronics, vol. 34, pp. 125-131, 2012.

[13] A. A. Elbashir, A. A. Ahmed, S. M. A. Ahmed, and H. Y. AboulEnein, "1, 2-Naphthoquinone-4-sulphonic acid sodium salt (NQS) as an analytical reagent for the determination of pharmaceutical amine by spectrophotometry," Applied Spectroscopy Reviews, vol. 47, pp. 219-232, 2012.

[14] Q. Li, J. Li, and Z. Yang, "Study of the sensitization of tetradecyl benzyl dimethyl ammonium chloride for spectrophotometric determination of dopamine hydrochloride using sodium 1,2-naphthoquinone-4-sulfonate as the chemical derivative chromogenic reagent," Analytica Chimica Acta, vol. 583, no. 1, pp. 147-152, 2007.

[15] P. Nagaraja, K. C. S. Murthy, K. S. Rangappa, and N. M. M. Gowda, "Spectrophotometric methods for the determination of certain catecholamine derivatives in pharmaceutical preparations," Talanta, vol. 46, no. 1, pp. 39-44, 1998.

[16] P. Nagaraja, R. A. Vasantha, and K. R. Sunitha, "A new sensitive and selective spectrophotometric method for the determination of catechol derivatives and its pharmaceutical preparations," Journal of Pharmaceutical and Biomedical Analysis, vol. 25, no. 3-4, pp. 417-424, 2001.

[17] P. Nagaraja, R. A. Vasantha, and K. R. Sunitha, "A sensitive and selective spectrophotometric estimation of catechol derivatives in pharmaceutical preparations," Talanta, vol. 55, no. 6, pp. 1039-1046, 2001.

[18] M. R. Hormozi Nezhad, J. Tashkhourian, and J. Khodaveisi, "Sensitive spectrophotometric detection of dopamine, levodopa and adrenaline using surface plasmon resonance band of silver nanoparticles," Journal of the Iranian Chemical Society, vol. 7, no. 1, pp. S83-S91, 2010.

[19] L. Guo, Y. Zhang, and Q. Li, "Spectrophotometric determination of dopamine hydrochloride in pharmaceutical, banana, urine and serum samples by potassium ferricyanide-Fe(III)," Analytical Sciences, vol. 25, no. 12, pp. 1451-1455, 2009.

[20] M. E. El-Kommos, "Spectrophotometric assay of dopamine hydrochloride injection using thiosemicarbazide," Journal de Pharmacie de Belgique, vol. 42, no. 6, pp. 371-376, 1987.

[21] S. Matsuoka and K. Yoshimura, "Recent trends in solid phase spectrometry: 2003-2009. A Review," Analytica Chimica Acta, vol. 664, no. 1, pp. 1-18, 2010.

[22] N. Silva and E. E. S. Schapoval, "Spectrophotometric determination of etidocaine in pharmaceutical (dental) formulation," Journal of Pharmaceutical and Biomedical Analysis, vol. 29, no. 4, pp. 749-754, 2002.
[23] A. Safavi, N. Maleki, O. Moradlou, and F. Tajabadi, "Simultaneous determination of dopamine, ascorbic acid, and uric acid using carbon ionic liquid electrode," Analytical Biochemistry, vol. 359, no. 2, pp. 224-229, 2006.

[24] T. Selvaraju and R. Ramaraj, "Simultaneous determination of ascorbic acid, dopamine and serotonin at poly(phenosafranine) modified electrode," Electrochemistry Communications, vol. 5, no. 8, pp. 667-672, 2003. 

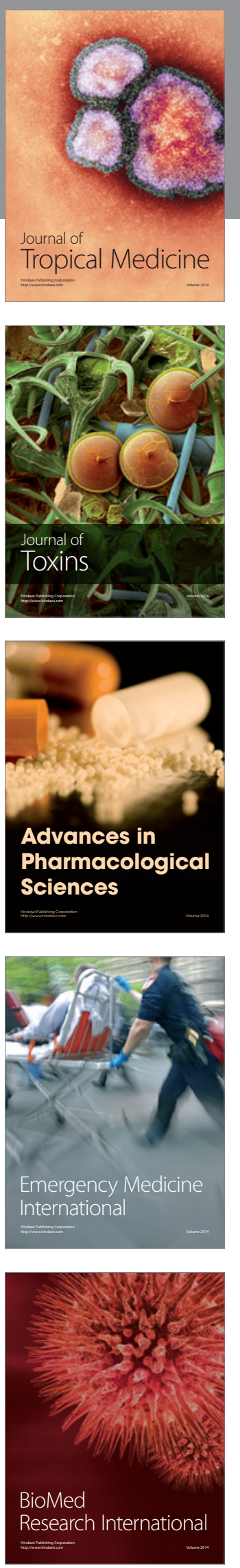
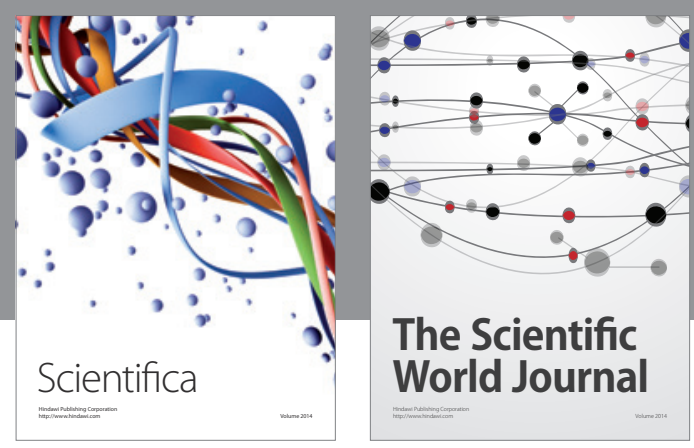

The Scientific World Journal
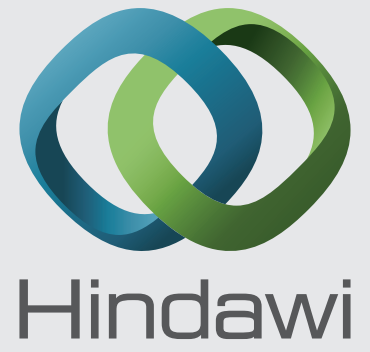

Submit your manuscripts at

http://www.hindawi.com
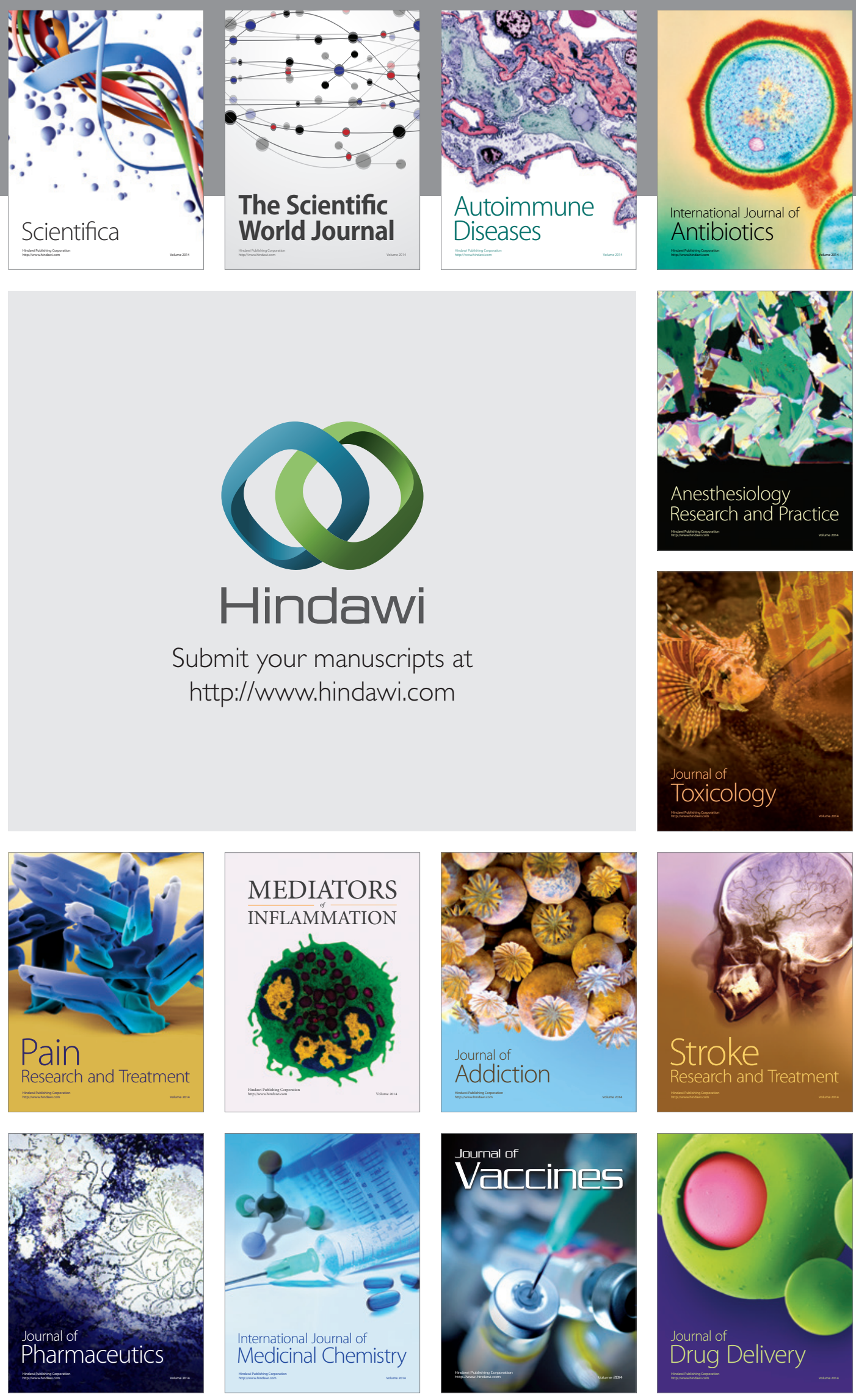